\title{
Chapter 17 \\ Diaspora Policies, Consular Services and Social Protection for Senegalese Citizens Abroad
}

\author{
Etienne Smith
}

\subsection{Diaspora Characteristics and Home Country Engagement Infrastructure}

\subsubsection{The Senegalese Diaspora and its Relations with the Homeland}

With a population of Senegalese abroad approaching one million for a total population of 15 millions, Senegal is unquestionably an emigration country. The Senegalese diaspora is estimated at a minimum of 550,000 and up to 2,5 million people by some estimates. Based on the most consistent and minimal figures, the Senegalese population abroad is divided primarily between Western Europe (approximately 280,000) and Sub-Saharan Africa (around 230,000), with the rest in North America (around 25,000), North Africa and the Middle East $(15,000)$ and very small numbers in Asia and South America. According to the estimations, the main destination countries in Europe comprise France (around 110,000), Italy $(80,000)$ and Spain $(60,000)$; in West Africa, mostly Gambia $(100,000)$, Mauritania $(40,000)$ and the Ivory Coast (20,000); in Central and Southern Africa, Gabon (20,000), Congo $(10,000)$ and South Africa (5,000); in North Africa and the Middle East, Morocco (10.000); in North America, the United States of America $(20,000)$ and Canada $(5,000)$ (Lessault and Mezger 2010; Smith 2015b; Ndione 2019).

Historically, Senegalese first emigrated to other African countries (West Africa and Central Africa) and France. Emigration flows diversified in the 1990s to include notably Italy, Spain and North America, as well as new destination countries in the Middle East (Saudi Arabia and Gulf states), North Africa (Morocco), Asia (China)

\footnotetext{
E. Smith $(\bowtie)$

Sciences Po Bordeaux, Bordeaux, France

e-mail: e.smith@sciencespobordeaux.fr
} 
and South America (Brazil, Argentina) (Bredeloup 1992; Robin and Lalou 2000; Tall 2002; Diop 2008; Fall 2013; Lessault and Flahaux 2013; Baizán et al. 2013; Beauchemin et al. 2014; Ndione 2019). Senegalese emigration is sociologically heterogeneous, combining historical flows of labour migration (industrial sector in France and Southern Europe, mining sector in West and Central Africa- see Bredeloup 1993; Beauchemin et al. 2014) in the 1960s and 1970s, followed by petty trade and informal sector (virtually everywhere, see Ebin and Lake 1990), student and highly-skilled migration (mainly in France, but also Switzerland, Belgium, North America, Morocco, or Asia- see Bava and Pliez 2009), and religious endeavours (Mboup 2001; Tandian 2008; Dia 2014; Berriane 2015).

\subsubsection{Diaspora Infrastructure}

Engagement with the diaspora started in the 1980s, when students and migrant workers in France were the two main categories of Senegalese abroad. In 1979, the Service for the Monitoring of Senegalese Students Abroad ${ }^{1}$ was created by the Ministry of Education. Hosted in the Embassy of Senegal in Paris, it manages governemental scholarships for Senegalese students abroad (payment, orientation and assistance for Senegalese students abroad) and is competent for Senegalese students worldwide. In 1983, a deputy-minister in charge of emigrants (ministre délégué chargé des émigrés) was appointed for the first time, primarily tasked with providing assistance to Senegalese in France (Fall 2010, p. 82). In a context of the first wave of forced repatriation of Senegalese migrants from France, the Office for Reception, Orientation and Monitoring of Emigrants ${ }^{2}$ was created in 1987 to provide assistance to returnees.

However, the real policy turn and first attempt at institutionalizing a comprehensive engagement with the diaspora occured in 1993, when the Ministry of Foreign Affairs's official name became the Ministry of Foreign Affairs and Senegalese Abroad $^{3}$ and with the creation within the Ministry of the General Directorate of Senegalese Abroad ${ }^{4}$. In charge of the promotion, protection and assistance to Senegalese nationals abroad, this Directorate became a Ministry of its own in 2003, known as the Ministry of Senegalese Abroad ${ }^{5}$. In 2012, it was reintegrated within the Ministry of Foreign Affairs and Senegalese Abroad. The General Directorate of Senegalese Abroad currently comprises two divisions: the Directorate for the Assistance and Promotion of Senegalese Abroad ${ }^{6}$, formerly known as the Directorate

\footnotetext{
${ }^{1}$ Service de Gestion des Étudiants Sénégalais à l'Étranger.

${ }^{2}$ Bureau d'Accueil, d'Orientation et de Suivi des émigrés (BAOS).

${ }^{3}$ Ministère des Affaires Etrangères et des Sénégalais de l'Extérieur (MAESE).

${ }^{4}$ Direction Générale des Sénégalais de l'Extérieur (DGSE).

${ }^{5}$ Ministère des Sénégalais de l'Extérieur (MSE).

${ }^{6}$ Direction de l'Assistance et de la Promotion des Sénégalais de l'Extérieur (DAPSE).
} 
for Social Affairs ${ }^{7}$, in charge of the protection and assistance to Senegalese abroad, and the Directorate for the Promotion of Investment and Projects ${ }^{8}$ responsible for the economic promotion of Senegalese abroad (Fall 2010; Toma and Kabbanji 2017). In 2017, the decree reorganizing the Ministry of Foreign Affairs and Senegalese Abroad mentions that the Minister "assists, as necessary, Senegalese abroad, encourages and coordinates the initiatives aimed at their gathering. It develops mechanisms for their economic, social and cultural reintegration as well as their access to housing and the promotion of their investment projects." 9

The Senegalese consular network is relatively large and well-funded for a developing country, with a diplomatic presence (embassies and consulates) in 49 countries (23 in Africa, 11 in Europe, 6 in the Middle East, 6 in Asia, 3 in the Americas). Initially, the consular network did not reflect the geography of Senegalese emigration, but rather historical ties and geopolitical motives (Western Europe, West African neighbouring countries, key countries in Africa like Nigeria or Ethiopia). However, the geography of diplomatic representations increasingly matches Senegalese emigration, with an increased presence in countries with major Senegalese communities like Spain and Italy, or with new destination countries in Latin America and Asia. Mobile consulate services are offered in some countries, notably for passport application, ID card application, and electoral register registration. A network of honorary consuls also exists. Honorary consuls are habilitated to provide assistance to Senegalese abroad (contacts, reaching out to local or home authorities, etc.), but they do not issue official documents.

Exceptional repatriation by consulates for health issues is possible, but only for severe health conditions. No formal rules apply as the decision remains at the discretion of the consulates and the Directorate for the Assistance and Promotion of Senegalese Abroad of the Ministry of Foreign Affairs and Senegalese Abroad..$^{10}$ In case of death, consulates help logistically with repatriation of bodies and administrative procedures, although there is no formal provision for financial support. When the family of the deceased duly declares the death, the consulate issues a "voucher" which reduces tax paid at customs for the repatriation of the deceased body.

A consultative institution, affiliated with the Ministry of Foreign Affairs and Senegalese Abroad, also exists. The Superior Council of Senegalese Abroad ${ }^{11}$ was officially created in 1995, and then again in 2010, after more than ten years of inactivity. It finally changed its name in 2014 to become the High Council of Senegalese

\footnotetext{
${ }^{7}$ Direction des Affaires Sociales (DAS).

${ }^{8}$ Direction de l'Appui à l'Investissements et aux Projets (DAIP)

${ }^{9}$ Décret $n^{\circ}$ 2017-1565 du 13 septembre 2017 relatif aux attributions du Ministre des Affaires étrangères et des Sénégalais de l'Extérieur, https://www.sec.gouv.sn/d\%C3\%A9cret-n\%C2\%B0\% C2\%A02017-1565-du-13-septembre-2017-relatif-aux-attributions-du-ministre-des-affaires. Last accessed 29 April 2020.

${ }^{10}$ Ministère des Sénégalais de l'Extérieur, Guide du Sénégalais de l'Extérieur. Mieux communiquer avec les compatriotes expatriés, Dakar, 2007, p. 23.

${ }^{11}$ Conseil Supérieur des Sénégalais de l'Etranger (CSSE).
} 
Abroad $^{12}$, but is still not fully functional. It has a consultative role on all matters regarding Senegalese abroad, and is supposed to meet twice a year in Dakar at the request of the Ministry of Foreign Affairs and Senegalese Abroad. Extraordinary meetings can also be organized at the request of two thirds of its members. The High Council is composed of: (1) members elected among Senegalese residing abroad duly registered with the Senegalese embassy and members of associations of Senegalese abroad duly recognized by the Ministry of Foreign Affairs or by the host country and; (2) members appointed by the President of the Republic ${ }^{13}$.

The major political parties have branches abroad, with a formal presence in the parties' organisation charts. ${ }^{14}$ Historically, these sections abroad have been particularly active in France, Italy, the United States, Spain and Gabon. Electoral campaigns often begin abroad and some presidential candidates have even launched their political campaign from abroad (Salzbrunn 2002; Smith 2015a). In countries like France, links with parties and trade unions of the host country have also developped throughout the years, especially at the local level.

Called émigrés or travailleurs migrants in official policy documents in the 1980s, the Senegalese nationals abroad have subsequently been named Sénégalais de l'étranger and finally Sénégalais de l'extérieur in the official nomenclature. ${ }^{15} \mathrm{In}$ 2007, the Ministry used the expression "expatriates" (compatriotes expatriés) in its official Handbook for Senegalese Abroad. ${ }^{16}$ Senegalese abroad are commonly referred as les émigrés and la diaspora in daily conversation and media reports. In Senegal, views about Senegalese abroad are mixed: a strong desire for migration and social emulation triggered by "success stories" of seeminly wealthy returnees cohabitate with criticism regarding lifestyle abroad (Riccio 2005; Diop 2008; Timera 2014). However, rather favourable overall views predominate as the financial flows from the diaspora are unanimously considered vital for the Senegalese economy (Ndione 2009; Somé 2009; OECD 2012). In 2017, these flows reached 2,2 billion US dollars, accounting for around 13\% of the Gross Domestic Product and more than twice the level of development aid (Ndione 2019, p. 17, 68).

\footnotetext{
${ }^{12}$ Haut Conseil des Sénégalais de l'Extérieur (HCSE).

${ }^{13}$ In its initial stage (1995-2000), the geographical distribution of its 60 elected members was the following: Africa (30), Europe (16), Americas (7), Middle East (6) and Asia (1). 15 members were appointed by the President of the Republic. In 2010, for the "re-creation" of the Council, 30 members were elected and 45 appointed by the President of the Republic.

${ }^{14} \mathrm{See}$, for instance, the Delegation for Senegalese Abroad (Délégation des Sénégalais de l'Extérieur) of Alliance pour la République (APR); the National Secretary for the Diaspora (Secrétaire National Chargé de la Diaspora) of Parti Démocratique Sénégalais (PDS); or the National Secretariat for Senegalese Abroad and Migration (Secrétariat National aux Sénégalais de l'extérieur et aux questions migratoires) of Parti Socialiste (PS).

15 "Les Sénégalais établis hors du Sénégal" is a term used only very recently, probably modelled on the expression in use in French policy documents when referring to French expatriates.

${ }^{16}$ Guide du Sénégalais de l'Extérieur. Mieux communiquer avec les compatriotes expatriés, Ministère des Sénégalais de l'Extérieur, Dakar, 2007.
} 


\subsubsection{Key Engagement Policies}

In 2001, the Government of Senegal held a symposium in Dakar to engage with associations of Senegalese abroad, which led to the autonomisation of the Direction Générale des Sénégalais de l'Extérieur and the creation of the Ministry of Senegalese Abroad in 2003. In 2006, the Ministry formalized the official policy commitments of the state towards its citizens abroad in a Policy Paper on Senegalese abroad ${ }^{17}$, later updated in 2011, sketching out the main priorities: consular registration and assistance, political representation, and economic promotion. In 2018, the Ministry issued its policy plan, drafted in partnership with the International Organization for Migration (IOM) and the United Nations Development Programme (UNDP). The National Migration Policy of Senegal ${ }^{18}$ reaffirms these main goals, while clearly prioritizing economic development in line with the national development plan of Senegal known as Plan Sénégal Emergent and regulation of emigration flows in line with the priorities of Senegal's main partners (France, Italy, and Spain).

\section{Registration and Administrative Documents}

Consulates are responsible for the upkeep of the Register of Senegalese Abroad ${ }^{19}$. Consular registration is optional for Senegalese abroad, but necessary in order to acquire a consular ID (carte consulaire), a national identity card and a voter's card (the same biometric card for the latter two). ${ }^{20}$ Only eight consulate generals (in France, Italy, Spain, the Ivory Coast, Gabon, Morocco, the United States, Saudi Arabia) are entitled to produce and deliver biometric passports directly to Senegalese abroad.

The Ministry of Foreign Affairs and Senegalese Abroad centralizes the consular register and has been carrying out a comprehensive census of Senegalese abroad since 2009. However, it has not yet been published. It also holds an official register of associations of Senegalese abroad. In 2008, a total of 741 such associations worldwide were registered with the Ministry.

All Senegalese consulates are habilitated to issue birth certificates for Senegalese born abroad in the jurisdiction of the consulate. Birth must be declared within one month and the birth certificate is issued free of charge by the Consulate within three to ten days (birth certificate of the host country and a valid ID must be produced).

\footnotetext{
${ }^{17}$ Lettre de Politique Sectorielle des Sénégalais de l'Extérieur, Ministère des Sénégalais de l'Extérieur, Dakar, 2006.

${ }^{18}$ Politique Nationale de Migration du Sénégal (PNMS).

${ }^{19}$ Registre des Sénégalais établis hors du Sénégal.

${ }^{20}$ If they do not register in the Register of Senegalese abroad or the register for external voting, Senegalese abroad can keep being registered as residents in Senegal, provided that they have proof of residence in Senegal. As a result, they can access health services provided to Senegalese residents.
} 


\section{Electoral Rights and Political Representation}

Adopted in 1992, external voting rights have allowed Senegalese abroad to participate in Senegalese presidential and legislative elections since 1993 (Dedieu et al. 2013; Smith 2015a, b). While initially only a handful of communities of Senegalese abroad could participate (for instance, only Senegalese from 15 countries in the 2000 elections), now Senegalese living in 49 countries participate in Senegalese elections. The electoral register for Senegalese abroad compiled by the Ministry of Foreign Affairs and Senegalese Abroad comprises more than 310,000 voters (in 2019), who are required to vote in person at a polling station in the country of residence. In 2016, in line with the argument that the Senegalese abroad constitute "the $15^{\text {th }}$ region of Senegal", special parliamentary representation for Senegalese abroad was introduced for the first time: 15 of the 165 seats in the National Assembly are now reserved for Senegalese abroad, i.e. just below $10 \%$. The implemention of this major constitutional reform took place during the legislative elections of $2017 .{ }^{21}$

\section{Economic Promotion}

Besides political rights, economic engagement with the diaspora is the key priority for the Governement of Senegal. Securing housing in Senegal was a major concern for Senegalese abroad in the 2000s. The Ministry of Foreign Affairs and Senegalese abroad hosted a division specifically dedicated to this task, the Directorate for the Promotion of Housing for Senegalese Abroad ${ }^{22}$. A program of "diaspora estates" was launched in two regions for Senegalese from France, the United States and Italy. The scheme monitored sale of land plots and five years loans for Senegalese abroad organized in associations and willing to pay $20 \%$ of the total construction costs (Tall 2009). These programs were not continued, but the Directorate for the Promotion of Investment and Projects ${ }^{23}$ continues to organize housing fairs abroad (Salons de l'habitat) to promote the purchase of real estate in Senegal by Senegalese abroad. Since 2012, a Interministerial Committee to help Senegalese abroad access housing in Senegal ${ }^{24}$ has been given the task to determine quotas for Senegalese abroad in accessing constructible land, provide information and assistance to Senegalese abroad to access funding facilities for housing.

During that same decade, the official discourse gradually shifted its priorities upon realizing that investment made by Senegalese abroad in real estate, transport or trade is not 'productive investment'. By the mid-2000s, the channelling of financial flows from Senegalese abroad towards productive investment (agriculture and agro-business, small businesses, etc.) became the top priority, being recently reiterated within the framework of the long-term development strategy for 2035 (Plan Sénégal Emergent).

\footnotetext{
${ }^{21}$ These extra-territorial seats are distributed as follows: Africa (7), Europe (6), America and Oceania (1), Asia and the Middle East (1).

${ }^{22}$ Direction de la Promotion de l'Habitat des Sénégalais de l'Extérieur (DIPHASE).

${ }^{23}$ Direction de l'Appui à l'Investissements et aux Projets (DAIP).

${ }^{24}$ Comité interministériel pour l'accès au logement des sénégalais établis à l'étranger.
} 
The major innovation in this respect has been the creation of the Investment Support Fund for Senegalese Abroad $^{25}$ in 2008. This investment and guarantee fund, under the auspices of the Directorate for the Promotion of Investment and Projects, promotes "productive investment" in Senegal by Senegalese abroad in any sector except real estate, trade and transport. Any Senegalese citizen residing abroad, holding a valid document proving residence abroad, and bringing a 10\% personal contribution to the project is eligible. Two mechanisms are in place: either direct loans or a guarantee provided for loans with private banks. Technical expertise is also provided.

In parallel, the Ministry of Economy and Finance has set up an Investment and Guarantee Fund for Senegalese Abroad ${ }^{26}$, as part of the broader FONGIP program ${ }^{27}$. This investment and guarantee fund is specifically for small businesses in priority sectors, as defined by the Ministry. It seeks to help Senegalese abroad access credit by decentralized financial services institutions in Senegal and to strengthen these decentralized financial services institutions in Senegalese regions, especially those contributing the most to international migration flows.

These two initiatives are part of the Policy Plan for Senegalese Abroad ${ }^{28}$ launched by the General Directorate for Senegalese Abroad as part of the Strategic Orientation Plan 2014-2017, which aimed at promoting the territorialization of migration in favour of local development.

Targetting the remittances of Senegalese abroad, promoting local development and encouraging return migration are seen as convergent and mutually reinforcing goals by the Ministry, as well as international partners of Senegal's migration policy (IOM; French, Spanish and Italian cooperation especially). A few joint initiatives have been experimented in the last decade:

- the Support Program for Solidarity Initiatives for Development ${ }^{29}$, launched in 2009. Jointly sponsored by the Senegalese Governement ${ }^{30}$ and French cooperation, its main goal is to provide support for private economic investment projects in Senegal by Senegalese residing in France. Two mechanisms exist: (1) financial (up to $70 \%$ of the projet) and technical support for associations of Senegalese nationals in France to set up local infrastructure development in their regions of origin in Senegal and; (2) mobilization of scientific and technically-skilled Senegalese from France for short assignments in Senegal. The program also

\footnotetext{
${ }^{25}$ Fond d'Appui à l'Investissement des Sénéglais de l'Extérieur (FAISE). Within the FAISE, a specific fund, Femmes de la diaspora, is devoted to projects led by women from the diaspora

${ }^{26}$ Fonds de Garantie pour l'Investissement des Sénégalais de l'Extérieur (FOGARISE).

${ }^{27}$ The FONGIP is a guarantee fund for priority investment set up by the Government in 2012.

${ }^{28}$ Plan d'action en faveur des Sénégalais de l'Extérieur.

${ }^{29}$ Programme d'Appui aux Initiatives de Solidarité pour le Développement (PAISD).

${ }^{30}$ The institutions responsable for the program in Senegal are the Direction de la Coopération Technique at the Secrétariat Général de la Présidence de la République du Sénégal, the Agence de Développement et d'Encadrement des Petites et Moyennes entreprises (ADEPME), the Direction Générale des Sénégalais de l'Extérieur of the Ministry of Foreign Affairs and Senegalese Abroad and the Senegalese embassy in Paris.
} 
includes the specific scheme Solidarity Volunteering for Development ${ }^{31}$ for second and third generation Senegalese born in France who are willing to participate in Senegal in community-development non-profit projects. ${ }^{32}$

- the Platform for the Support of the Private Sector and Valorisation of the Senegalese Diaspora in Italy. ${ }^{33}$ This program is a partnership between the Microfinance Division of the Ministry of SME(s), Women Entreneurship and Microfinance of Senegal and the Ministry of Foreign Affairs of Italy and the Piemonte region in Italy. The Platform provides credit support, loan rate guarantees and technical expertise for small businesses run by Senegalese nationals residing in Italy who invest in Senegal (Italians willing to create a small business in Senegal are also eligible).

In 2016, the Ministry of Foreign Affairs and Senegalese Abroad launched the first Support Office for Senegalese Abroad ${ }^{34}$ outside Senegal, located with the consulate general of Senegal in Milano. Working as a liaison office for the FAISE, FONGIP and PLASEPRI national programs, it is mainly an orientation and support office providing information for Senegalese in Italy willing to invest in Senegal. After this first experiment, the policy goal is to multiply these Support Offices abroad in key countries with significant Senegalese migrant communities.

The return of Senegalese migrants is also one of the clearly stated long-term goals of the FAISE and PLASEPRI programs. ${ }^{35}$ The still existing Office for Reception, Orientation and Monitoring of Emigrants ${ }^{36}$ provides information for aspiring migrants, first-degree family members with a relative abroad or returnees with the aim, in the latter case, of facilitating socio-economic reintegration. It now has sub-branches in the regions of Senegal with most emigrants.

Overall, the engagement of the Senegalese state with its citizens abroad has clearly intensified over the years, along its two most salient priorities: political representation and tapping into the resources of the diaspora. Despite being defined as a legitimate policy goal by official policy papers, social protection for Senegalese abroad lags behind drastically, especially when compared with the progress noted in the two aforementioned policy areas. The main reason is, of course, the embryonic state of social protection in Senegal itself in many branches, but also the absence of a strong and specifically dedicated institution tasked with advancing social

\footnotetext{
${ }^{31}$ Volontariat de Solidarité pour le Développement.

${ }^{32}$ www.codev.gouv.sn. Last accessed 29 April 2020.

${ }^{33}$ Plateforme d'appui au secteur privé et à la valorisation de la diaspora sénégalaise en Italie (PLASEPRI).

${ }^{34}$ Bureau d'Appui aux Sénégalais de l'Extérieur (BASE).

${ }^{35}$ In the period 2006-2007, a sectorial policy was initiated jointly by Spain and Senegal for the return of emigrants to agriculture (Plan REVA Retour des Emigrés Vers l'agriculture). The main goal of this 20 million euros scheme funded by the Spanish cooperation was to foster jobs in the agricultural sector for Senegalese returnees from Spain. Although the program was discontinued, some imitative measures to foster investment and return in agriculture are still in place, e.g. the reservation of $20 \%$ arable land for Senegalese abroad.
}

${ }^{36}$ Bureau d'Accueil, d'Orientation et de Suivi des émigrés (BAOS). 
protection for emigrants. The lack of basic protection and pro-active state policy is only partially made up by the self-help schemes and vibrant associational life of Senegalese abroad (Dia 2007, 2010; Tandian and Coulibaly-Tandian 2016; Hunter 2018).

\subsection{Diaspora Policies and Social Protection in Senegal}

As a general rule, in all matters related to social protection, a strict principle of territoriality and residence applies in Senegal (Fall 2003; Tounkara 2009; Baumann 2010). As a result, emigrants lose their rights when they settle abroad, with very few exceptions detailed below. The Labour Law, Social Security Law and the founding texts of the Institute for Pension Plans of Senegal ${ }^{37}$ contain no specific disposition for emigrants.

\section{Information Policy}

Within the Ministry of Foreign Affairs and Senegalese Abroad, the Directorate for the Assistance and Promotion of Senegalese Abroad and the consular network have the mission to provide basic information and administrative assistance to Senegalese abroad. In 2007, the Ministry of Senegalese Abroad, published the Handbook for Senegalese Abroad, a 121 pages brochures with basic information about assistance and the role of consulates and the Ministry. Information provided about assistance is primarily focused on repatriation of corpses, i.e the administrative assistance that consulates and the Ministry can provide. Consulates help logistically with the repatriation of bodies and administrative procedures, but no formal provision for financial assistance exists. Exceptional financial help is at the discretion of the Directorate for the Assistance and Promotion of Senegalese Abroad. When the family of the deceased duly declares the death, consulates issue a "voucher" which reduces tax paid at customs for the repatriation of the corpse. In practice, the costs are covered by self-help associations, some of which have been structuring themselves as sociétés de secours mutuel, but the Ministry plays no part in these associations, except for holding the register and disseminating their contacts. One noteworthy exception is the particular case of repatriation of murdered individuals: the Ministry has made it an unwritten rule to cover the costs of repatriation of Senegalese abroad who were murdered $^{38}$.

Abroad, only Senegalese in France benefit from the presence of a social affairs attaché (assistante sociale) at the consulate general of Senegal in Paris. The attaché provides protection and legal assistance for Senegalese in France in situation of distress or facing legal issues, but no detailed specific information is provided online.

\footnotetext{
${ }^{37}$ Institut de Prévoyance Retraite du Sénégal (IPRES).

${ }^{38}$ Interview with Mr. Sory Kaba, Head of the General Directorate for Senegalese Abroad, Dakar, January 8, 2019. Quite a few cases of murders of Senegalese abroad have been mediatized in recent years in Italy, France, Spain, the United States, Brazil, the Ivory Coast or Morocco.
} 
In Senegal, the Social Security Board ${ }^{39}$ provides specific information to family members in its national office (with a dedicated office for migrants and their family members within the Division for Social Protection for Emigrants ${ }^{40}$ and its regional branches).

\section{Bilateral Conventions on Social Protection}

As of 2018, the bilateral convention on social protection between France and Senegal, signed in 1974, is the only convention that has been implemented. Specific information is provided by the social affairs attaché at the consulate general in Paris for Senegalese living in France who can benefit from the application of the convention, which currently covers only family allowances (see below).

Senegal also signed bilateral conventions with Mali (1965, renegociated in 1996) and Mauritania (1972, renegociated in 1987), which are very limited in scope. ${ }^{41} \mathrm{~A}$ convention was signed with Cabo Verde (1998), although it is not implemented yet. Conventions with Gabon and Cameroon have also been drafted, but not been ratified (Tounkara 2009, p. 23-24). During the last decade, Senegal has been negotiating with Spain and Italy for bilateral conventions, but no agreement has been reached yet about their future perimeter and the set of rights to include.

\section{Multilateral Conventions on Social Protection}

In 1993, 14 Member States of the Zone Franc in Africa established a dedicated institution for the harmonisation of social protection regimes, the Inter-African Conference on Social Welfare (CIPRES) ${ }^{42}$ based in Lomé (Togo). The major policy goal of CIPRES is to help Member States coordinate their social protection regimes, with the explicit objective of improving social protection for migrant workers in Member States, as stated in the Preamble and article 1 of the CIPRES Treaty of 1993. In February 2006, the CIPRES multilateral convention on social security was adopted in Dakar. This convention upholds the principle of the continuation of acquired rights for migrants (allowing for the suspension of the territoriality principle and the transferability of pension and health insurance rights) and equality of treatment between citizens of signatory states. However, this convention, ratified by Senegal in 2014 only, has been ratified by only seven out of the 17 signatory states. ${ }^{43}$ Short of a functional multilateral convention, payment agreements have been

\footnotetext{
${ }^{39}$ Caisse de Sécurité Sociale (CSS).

${ }^{40}$ Division de la Sécurité Sociale des Emigrés.

${ }^{41}$ The convention with Mali is merely an administrative agreement between the Social Security Boards of each country to facilitate the payment of workplace accident or disease benefits for posted workers (travailleurs détachés) on the territory of the other state for less than one year. See: Arrangement administratif général relatif aux modalités d'application de la convention générale sur la Sécurité Sociale entre la République du Sénégal et la République du Mali, Bamako, 25 July 1996. With Mauritania, disagreement about the level of family benefits have stalled the process (Tounkara 2009, p. 23), as well as currency exchange rate (Ndione 2019, p. 110).

${ }^{42}$ Conférence Interafricaine de la Prévoyance Sociale (CIPRES).

${ }^{43}$ Current members of CIPRES include: Benin, Burkina Faso, Cameroon, C.A.R., Congo, Côte d'Ivoire, Gabon, Guinea-Bissau, Equatorial Guinea, Madagascar, Mali, Niger, D. R. C., Senegal, Tchad, Togo, Comoros.
} 
negotiated bilaterally between the Social Security Board (CSS) and the Institute for Pension Plans of Senegal (IPRES) with their partner institutions in the Ivory Coast, Benin, Togo, Mali and Burkina Faso. ${ }^{44}$

As a Member State of both the Economic Community of West African States (ECOWAS) and West African Economic and Monetary Union (WAEMU), Senegal has signed the treaties and protocols of both institutions allowing for the free circulation and settlement of citizens from each Member State in all others Member States. To this day, no social protection agreements have been implemented through ECOWAS, although a regional social policy framework is clearly on the agenda. ${ }^{45}$

\subsubsection{Unemployment}

There is no policy of unemployment benefits in Senegal. The only unemployment benefits Senegalese abroad can access are the schemes available in their host countries, depending on the legislation applicable in each case.

\subsubsection{Health Care}

Until the mid-2000s, health care provisions in Senegal were only accessible for workers in the public sector and formal private sector. In the last decade, major policy reforms occured to broaden access to health care for workers in the informal sector, children under the age of 5, students and the elderly. ${ }^{46}$ So far, however, these schemes have not been extended to emigrants because the priority remains to extend national coverage first.

The Division for Social Protection for Emigrants of the Social Security Board of Senegal provides brief information about access to social protection programs available for Senegalese citizens living in France (and only them) in its brochure Handbook for Emigrants ${ }^{47}$. However, only posted workers (travailleurs détachés) in

\footnotetext{
${ }^{44}$ As of 2018, only the mutual payment agreements signed with the Ivory Coast, Togo and Burkina Faso were fully operational (Ndione 2019, p. 111).

${ }^{45}$ In spring 2018, the Social Affairs Division of the ECOWAS Commission, in partnership with UNICEF and ILO was recruiting a social protection expert to draft a policy framework with the goal of setting regional standards and guidelines for social protection policies and strategies in the ECOWAS.

${ }^{46}$ See for instance the Plan Sésame, initiated in 2006, providing free basic health care for the elderly, and the Couverture Maladie Universelle launched in 2012, aiming at the gradual extension of basic health care through mutual health insurance. Health care insurance coverage has increased from $7 \%$ in 2013 to $20 \%$ in 2016. Membership in mutual health insurance organisations has reached around 5,3 million (in 2017).

${ }^{47}$ Caisse de Sécurité Sociale du Sénégal, Guide des émigrés, http://www.secusociale.sn/docu. html\#guiem. Accessed 4 April 2018.
} 
France are eligible for the continued access to Senegalese social security benefits in the area of health care for a maximum period of three years (with possible exceptional extensions). All other Senegalese emigrants in France are encouraged to seek access to health and invalidiy schemes provided by France and check their eligibility status with these programs.

\subsubsection{Pensions}

Senegalese citizens entitled to claim their right to retirement from Senegal and who choose to settle abroad may receive their pension provided that they have a bank account where the transfers will be made. The Institute for Pension Plans of Senegal (IPRES) has a specific section of its website dedicated to Senegalese abroad, yet with relatively little information. ${ }^{48}$ Within the consular network, only the consulate general in France provides information on the bilateral convention between France and Senegal through its social affairs attaché. However, the convention applies to Senegalese workers in France willing to return to Senegal and keep the benefit of their French pension ${ }^{49}$, and not to Senegalese in France willing to keep the benefit of their Senegalese pension ${ }^{50}$.

Emigrants have consistently called for the renegociation of the bilateral convention between France and Senegal in order to better accommodate the needs of Senegalese workers and pensioners. However, as in other fields of social protection, the most pressing issue for the Governement is to increase national coverage before addressing the case of emigrants' access.

\subsubsection{Family-Related Benefits}

Family benefits in Senegal (allocations familiales) exist for workers in the public sector and the formal private sector. Senegalese abroad are not eligible for these programs, except those residing in France.

\footnotetext{
${ }^{48} \mathrm{www}$. ipres.sn/institut/index.php?option $=$ com_content $\&$ view $=$ article $\& i d=67 \&$ Itemid $=90$. Accessed 4 April 2018.

${ }^{49}$ This is possible only for contributory pension schemes within the general regime, not for noncontributory benefits such as the guaranteed minimum for the elderly (minimum vieillesse) which requires residence in France (at least six months per year). Retired Senegalese migrants returning to Senegal, even when eligible to French pensions, may nonetheless face visa or residence permit issues with the French administration that can affect their ability to effectively access their pension scheme.

${ }^{50}$ Convention du 29 mars 1974 entre le Gouvernement de la République Française et le Gouvernement de la République du Sénégal sur la Sécurité Sociale, modifiée par l'avenant du 21.12.1922 en vigueur le 01.06.1994 (décret n94-513 du 20.06.1994).
} 
In application of the 1974 Franco-Senegalese bilateral convention on social security, the Social Security Board of Senegal (CSS), through its dedicated Division for Social Security for Emigrants, is responsible for the payment of French family allowances to the family members (spouse and children) in Senegal of Senegalese workers living in France (pre-birth, birth and family benefits for up to four children until 18 years old or 21 years old if students). The French Family Allowances Office $^{51}$ transfers the allowances money to the Social Security Board of Senegal. This scheme requires the yearly certification of the family certificate by the Social Security Board of Senegal and the consulate general in Paris. Payment occurs in cash at the regional offices of the Social Security Board of Senegal. Additionally, four times a year, mobile payment teams circulate at the village level (10-day tours) for the three regions with most emigrants (Saint-Louis, Matam and Tambacounda). The Social Security Board of Senegal also cooperates regularly with its French equivalent for the transmission of relevant documents and certificates, which transit through the consulate general of Senegal in Paris. Moreover, Senegalese in France have access to a personal account on the online portal of the Social Security Board of Senegal, which has a specific section of its website dedicated to Senegalese in France (Espaces émigrés).

The consulate general in Paris is specifically tasked with providing relevant information for Senegalese workers in France about Senegalese family allowances for their family members residing in Senegal. It participates in the certification and transmission of relevant documents (état de famille- family certificate) to the Family Allowances Office in France and the Social Security Board in Sénégal.

\subsubsection{Economic Hardship}

There is no nationwide program in Senegal providing a guaranteed minimum resources scheme. Launched in 2013, the National Program of Allowances for Family Safety ${ }^{52}$ targets the most vulnerable households. Selected households receive 100,000 FCFA (150 euros) per year during five years. In exchange, families must enroll children in school, registry office and vaccination programs. The program is run by the General Delegation for Social Protection and National Solidarity ${ }^{53}$. In 2018, 300,000 families benefitted from this program. However, emigrants are not eligible to apply. Self-help associations among Senegalese abroad and remittances from Senegalese abroad constitute one of the many informal social safety nets put in place by emigrants for themselves or for their relatives in Senegal in the absence of a state policy in this domain (Tandian and Coulibaly-Tandian 2016).

\footnotetext{
${ }^{51}$ Caisse d'Allocations Familiales.

${ }^{52}$ Programme national de bourses de sécurité familiale (PNBSF).

${ }^{53}$ Délégation générale à la protection sociale et à la solidarité nationale (DGPSN).
} 


\subsection{Conclusions}

In matters of social protection, Senegalese emigrants are, for the most part, left to their own devices. Reform of the Senegalese legislation and introduction of the principle of the portability of social protection rights is regularly called for by associations of Senegalese emigrants, especially for health care and invalidity. Despite persistent demands for a voluntary insurance scheme backed by the Governement for emigrants or the creation of a dedicated and comprehensive institution for the social protection of emigrants, little policy improvement has yet materialized.

In response to the grievances of the diaspora, the state of Senegal rather prioritises the gradual extension of domestic coverage in Senegal through its universal health care scheme (planning to increase coverage from $20 \%$ to $50 \%$ ), while also pursuing its policy of negotiating bilateral conventions on social protection with new countries with large numbers of Senegalese citizens (Italy, Spain). However, even when a bilateral convention exists, reciprocity does not function well when social protection policies are found lacking in the sending state or when the destination country prioritises the management of return migration over the extension of new rights. According to emigrant associations and policy experts, the only working convention to date, i.e. between France and Senegal, also needs to be reformed as its scope remains very limited (family allowances only).

There is much room for change in the future however, as the economic weight of the diaspora keeps increasing and the allocation of the 15 new seats to the diaspora in the Parliament could amplify the political voice of Senegalese abroad advocating policy change, depending though on the extent to which these new representatives of Senegalese abroad will take on their new role.

Acknowledgements This chapter is part of the project "Migration and Transnational Social Protection in (Post)Crisis Europe (MiTSoPro)" that has received funding from the European Research Council (ERC) under the European Union's Horizon 2020 research and innovation programme (Grant agreement No. 680014). In addition to this chapter, readers can find a series of indicators comparing national social protection and diaspora policies across 40 countries on the following website: http://labos.ulg.ac.be/socialprotection/.

\section{References}

Baizán, P., Beauchemin, C., \& González-Ferrer, A. (2013). Determinants of migration between senegal and France, Italy and Spain (MAFE Working Paper 25). Paris: INED.

Baumann, E. (2010). Protections sociales en Afrique subsaharienne. Le cas du Sénégal (Note de la Fondation Jean Jaurès, $\mathrm{n}^{\circ}$ 56). Paris: Fondation Jean Jaurès.

Bava, S., \& Pliez, O. (2009). D'Al Azhar à l'économie de bazar. Itinéraires socio-économiques des « élites musulmanes » africaines au Caire. Afrique Contemporaine, 3(231), 187-207.

Beauchemin, C., Sakho, P., Schoumaker, B., \& Flahaux, M.-L. (2014). New Patterns of migration betweeen Senegal and Europe (MAFE Working Paper 21). Paris: INED.

Berriane, J. (2015). Sub-Saharan students in Morocco: determinants, everyday life, and future plans of a high-skilled migrant group. The Journal of North African Studies, 20(4), 573-589. 
Bredeloup, S. (1992). Itinéraires africains des migrants sénégalais. Hommes et Migrations, $1160,16-22$.

Bredeloup, S. (1993). Les migrants du fleuve. À quand la Diams'pora. Revue européenne de migrations internationales, 9(1), 67-93.

Dedieu, J.-P., Gubert, F., Chauvet, L., Mesplé-Somps, S., \& Smith, E. (2013). The "Battles" of Paris and New York. An analysis of the transnational electoral behaviour of senegalese immigrants in France and the United States. Revue Française de Science Politique, 63(5), 865-892.

Dia, H. (2007). Les investissements des migrants dans la vallée du fleuve Sénégal: confiance et conflits d'intérêts. Revue européenne des migrations internationales, 23(3), 29-49.

Dia, H. (2010). Les villages "multi-situés" sénégalais face à la nouvelle configuration migratoire mondiale. Hommes \& Migrations, 1286-1287(4), 234-244.

Dia, H. (2014). Figures étudiantes sénégalaises à l'étranger. Hommes \& migrations, 1307, 95-103.

Diop, M.-C. (Ed.). (2008). Le Sénégal des migrations. Mobilités, identités et sociétés. Paris and Dakar: Karthala-CREPOS.

Ebin, V., \& Lake, R. (1990). Camelots à New York: les pionniers de l'immigration sénégalaise. Hommes et Migrations, 1132, 32-37.

Fall, P. D. (2003). Migration internationale et droits des travailleurs au Sénégal. Paris: UNESCO.

Fall, P. D. (2010). Diaspora et développement durable au Sénégal: un état des lieux de la politique gouvernementale de 2000 à nos jours. Amsterdam: African Diaspora Policy Center (ADPC).

Fall, P. D. (2013). Des Francenabé aux Modou-Modou. Géographie de la migration internationale des Sénégalais. Dakar: Thèse de Doctorat d'Etat, Université Cheikh Anta Diop.

Hunter, A. (2018). Retirement Home? Ageing Migrant Workers in France and the Question of Return. Cham: Springer.

Lessault, D., \& Flahaux, D. (2013). Regards statistiques sur l'histoire de l'émigration internationale au Sénégal. Revue Européenne des Migrations Internationales, 29(4), 59-88.

Lessault, D., \& Mezger, C. (2010). La migration internationale sénégalaise. Des discours publics à la visibilité statistique. Paris: INED, MAFE Working Paper 5.

Mboup, M. (2001). Les Sénégalais d'Italie. Emigrés, agents du changement social. Paris: L'Harmattan.

Ndione, B. (2009). Les transferts de fonds et de compétences des émigrés: enjeux socioéconomiques et stratégie politique au Sénégal. Geneva: IOM.

Ndione, B. (2019). Migration au Sénégal: Profil national 2018. Geneva: IOM.

OECD. (2012). Senegal. In Connecting with emigrants: A global profile of diasporas. OECD Publishing.

Riccio, B. (2005). Talkin' about Migration. Some Ethnographic Notes on the Ambivalent Representation of Migrants in Contemporary Senegal. Stichproben, Wiener Zeitschrift für kritische Afrikastudien, 8, 99-118.

Robin, N., \& Lalou, R. (2000). Facteurs d'attraction et de répulsion à l'origine des flux migratoires internationaux au Sénégal. Brussels and Dakar: Eurostat; IRD.

Salzbrunn, M. (2002). La campagne présidentielle sénégalaise en France. Hommes et Migrations, $1239,49-53$.

Smith, E. (2015a). La diaspora fait-elle l'élection ? Le vote des Sénégalais de l'extérieur (1992-2012). Afrique Contemporaine, 256, 51-72.

Smith, E. (2015b). Carte électorale externe et cartographie des migrations sénégalaises. Afrique Contemporaine, 256, 114-116.

Somé, A. N. (2009). Migration au Sénégal: Profil national 2009. Geneva: IOM.

Tall, S. M. (2002). L'émigration internationale sénégalaise d'hier à demain. In M.-C. Diop (Ed.), La société sénégalaise entre le local et le global (pp. 549-577). Paris: Karthala.

Tall, S. M. (2009). Investir dans la ville africaine. In Les émigrés et l'habitat à Dakar. Paris and Paris: Karthala-CREPOS.

Tandian, A. (2008). Des migrants sénégalais qualifiés en Italie: entre regrets et résignation. In M.-C. Diop (Ed.), Le Sénégal des migrations: Mobilités, identités et sociétés (pp. 365-388). Paris and Dakar: KARTHALA-CREPOS. 
Tandian, A., \& Coulibaly-Tandian, O. K. (2016). Protection sociale des enfants de migrants originaires de Kébémer et Louga (Sénégal). Boletín de Antropología, 51(31), 113-132.

Timera, M. (2014). Mots et maux de la migration. De l'anathème aux éloges. Cahiers d'études africaines, 213-214, 27-47.

Toma, S., \& Kabbanji, L. (2017). Emigration and development in senegal. In A. Weinar (Ed.), Emigration and diaspora policies in the age of mobility (pp. 157-172). Cham: Springer.

Tounkara, C. T. (2009). Protection sociale des travailleurs migrants sénégalais et de leurs familles. Diagnostic et recommandations. Geneva: Bureau International du Travail, Dakar: Ministère des Sénégalais de l'Extérieur.

Open Access This chapter is licensed under the terms of the Creative Commons Attribution 4.0 International License (http://creativecommons.org/licenses/by/4.0/), which permits use, sharing, adaptation, distribution and reproduction in any medium or format, as long as you give appropriate credit to the original author(s) and the source, provide a link to the Creative Commons license and indicate if changes were made.

The images or other third party material in this chapter are included in the chapter's Creative Commons license, unless indicated otherwise in a credit line to the material. If material is not included in the chapter's Creative Commons license and your intended use is not permitted by statutory regulation or exceeds the permitted use, you will need to obtain permission directly from the copyright holder. 